Adjacent to this crevasse were several other much larger ones which were reported as being up to roo ft. $(30.5 \mathrm{~m}$.) wide. Unfortunately, no depth measurements were made on any of these very wide crevasses, but some of them may possibly be over $85 \mathrm{ft}$. deep.

I 47-A Newton St.,

Weston 93, Mass., U.S.A.

22 May 1955

Weston Blake, Jr.

In reply to a communication Mr. Blake wrote further :-

In reply to your request for total depths of the ice in the crevassed areas near the margin of the ice cap I can say that the ice is usually about 1000-1500 $\mathrm{ft}$. $(305-457 \mathrm{~m}$.) thick in these localities. Ice-depth measurements were made at several of these crevasses in 1953 by both seismic means and gravimeter surveys, and the results obtained coincided almost exactly. Further depth measurements were made in 1954 (including some in the vicinity of the largest-the $25 \mathrm{ft}$. wide, $80 \mathrm{ft}$. deep one I mentioned), but unfortunately I have not seen the results of this work. Neither do I have any temperature data on the crevasses.

It is to be noted that the possible existence of deeper crevasses in this area is not excluded. $E d$.

\title{
Le premier emploi de la photogrammétrie
}

Cher Monsieur,

Dans le très intéressant article publié par le fournal of Glaciology, Vol. 2, No. 15, 1954, p. 306-12, M. le Professeur Finsterwalder fixe en I9I3 le premier emploi de la photogrammétrie pour le levé de tout ou partie d'un glacier en dehors des Alpes. Cette indication n'est pas exacte : Alfred de Quervain, dans son premier voyage au Groenland en 1909 , a déjà appliqué la méthode photogrammétrique à la topographie de l'effluent de l'Inlandsis, le Grand Karajak, dans le district d'Umanak. Au cours de l'Expédition Suisse transgroenlandaise, dirigée par de Quervain aussi, j'ai appliqué en 1912 la photogrammétrie terrestre d'une part au levé du front de l'Eqip Sermia et d'autre part à celui de l'extrêmité du Sermeq Kujatdleq un autre effuent de l'Inlandsis, se terminant sur terre ferme, dans la même région. Je me suis alors servi précisément de la chambre photographique construite à Munich par le mécanicien Sedlbauer, suivant l'inspiration et sous le contrôle du regretté Sébastien Finsterwalder, l'éminent glaciologue, père de notre collègue Richard Finsterwalder.

Je crois utile de préciser ce début de l'emploi de l'application de la photogrammétrie à l'étude des glaciers polaires.

Veuillez recevoir, cher Collègue, mes bonnes salutations.

Commission Hélvétique des Glaciers (S.H.S.N.),

P.-L. Mercanton

Lausanne, le 2 r juin 1955

\section{O B I T U A R Y}

PHILIPS CHRISTIAN VISSER, I $882-1955$

H. E. Dr. PH. C. VISSER was born at Schiedam and, in his early manhood, spent some years with the family business in that town. At the age of twenty he made his first acquaintance with high mountains and soon became an enthusiastic mountaineer. In 1913 he was made a member of the Alpine Club in London.

In 1914 he took part in an expedition to the Caucasus, but the First World War put a stop to such expeditions and soon after his return he became Secretary to the Netherlands ambulance in Russia. In I9I9 he was appointed Secretary to the Netherlands Legation in Stockholm. In I93 I 